\title{
MECHANISM OF THE POSITIVE CEPHALIN-CHOLESTEROL FLOCCULATION REACTION IN HEPATITIS
}

\author{
By DAVID B. MOORE, PAUL S. PIERSON, FRANKLIN M. HANGER, AND \\ DAN H. MOORE \\ (From the Department of Medicine, and the Electrophoresis Laboratory, College of Physicians \\ and Surgeons, Columbia University, New York City)
}

(Received for publication July 5, 1944)

An alteration of the blood serum proteins in patients with catarrhal jaundice has been amply established by the development of a positive cephalin flocculation (1). A standard emulsion composed of cephalin and cholesterol, which remains stable in $0.2 \mathrm{ml}$. to $0.1 \mathrm{ml}$. normal serum, diluted $1: 21$, tends to flocculate and precipitate when added under identical conditions to the serum of patients with catarrhal jaundice. As the disease subsides, the positive reaction returns to negative. The mechanism of the reaction has not been adequately explained.

We have shown in unpublished experiments that a positive reaction is accompanied by the absorption of globulin by the emulsion particles, since rabbits immunized intravenously with washed flocculated material develop precipitins for the globulin components of both the euglobulin and pseudoglobulin fractions of human serum. The intensity of the precipitin reaction is the same with normal serum and with that from hepatitis, indicating that the absorbed protein does not differ antigenically from the globulin of normal serum.

The mechanism of the cephalin-cholesterol flocculation reaction has been investigated (2) and it was found that the gamma globulin fraction of the serum was the sole component giving a positive flocculation, and further that there was no difference in the flocculating power of the gamma globulin fraction obtained electrophoretically from a normal serum giving a negative reaction and the gamma globulin obtained from a hepatitis serum giving a strongly positive reaction. It was inferred that the negative flocculation obtained with normal sera was due to the inhibiting action by some other component of the serum. Complete inhibition of the reaction was not obtained with the albumin fraction in the proportions used by these observers, although inhibition of the colloidal gold reaction, which showed many points of similarity, was obtained with electrophoretically separated albumin. The present report is an extention of the studies mentioned above, including the use of gamma globulin and albumin in amounts comparable to those occurring in $0.1 \mathrm{ml}$. of whole serum.

\section{EXPERIMENTAL}

Serum was taken from a number of normal human subjects giving a negative flocculation reaction and from 2 patients with obvious liver disease giving strongly positive $(+++)$ flocculation reactions. Patient 1 was suffering from acute fulminating post-arsphenamine hepatitis. Patient 2 was in the first week of catarrhal jaundice. Electrophoretic analysis and separation of the sera were carried out in the Tiselius apparatus, using a buffer consisting of $0.02 M$ sodium phosphate $+0.15 M \mathrm{NaCl}$, at

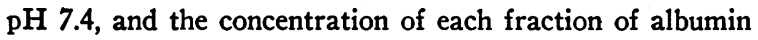
and gamma globulin obtained was determined by measuring its refractivity in a previously calibrated Zeiss interferometer.

Cephalin flocculation tests were performed on these separated serum fractions, in the manner previously described (3), using diminishing amounts of the gamma globulin fraction alone, and also after the addition of various albumin fractions. The protein preparations were mixed with $4 \mathrm{ml}$. of merthiolated saline and $1 \mathrm{ml}$. of standard cephalin-cholesterol emulsion. The tubes were allowed to stand at room temperature for 48 hours. Readings were made at 24 and 48 hours and recorded in terms of negative to ++++ .

\section{RESULTS}

\section{The effect of increasing dilution of the isolated gamma globulin fractions on cephalin- cholesterol flocculating properties}

The observations of others (2) on the cephalincholesterol flocculating properties of gamma globulin were confirmed and extended by adding decreasing amounts of the isolated gamma globulin preparations, from various sources, to a series of tubes containing $4 \mathrm{ml}$. saline and standard cephalincholesterol emulsion, to determine the degree of 
TABLE I

Cephalin flocculation shown by diminishing amounts of the isolated gamma globulin fraction of normal sera and of sera of hepatitis cases

\begin{tabular}{|c|c|c|c|c|c|}
\hline & \multicolumn{5}{|c|}{ Gamma globulin fraction in diminishing amounts } \\
\hline & $\begin{array}{l}0.55 \text { to } \\
0.65 \\
\mathrm{mgm} .\end{array}$ & $\begin{array}{l}0.44 \text { to } \\
0.52 \\
\mathrm{mgm} .\end{array}$ & $\begin{array}{c}0.33 \text { to } \\
0.39 \\
\text { mgm. }\end{array}$ & $\begin{array}{l}0.22 \text { to } \\
0.26 \\
\mathrm{mgm} .\end{array}$ & $\begin{array}{c}0.11 \text { to } \\
0.13 \\
\mathrm{mgm} .\end{array}$ \\
\hline $\begin{array}{l}\text { Normal case I } \\
\text { Normal case II } \\
\text { Normal case III } \\
\text { Normal case IV } \\
\text { Hepatitis case I } \\
\text { Hepatitis case II }\end{array}$ & & & & $\begin{array}{c}+++ \\
++ \\
\pm \\
+ \pm+ \\
++\end{array}$ & $\begin{array}{l}\mathbf{1} \\
\mathbf{0} \\
\mathbf{0} \\
\mathbf{0} \\
\mathbf{0} \\
\mathbf{0}\end{array}$ \\
\hline
\end{tabular}

dilution necessary to obliterate the flocculation (Table I).

It will be noted that as the gamma globulin fractions are progressively diluted, the flocculation diminishes, and is usually abolished at a concentration between 0.22 and $0.11 \mathrm{mgm}$. of gamma globulin in $5.2 \mathrm{ml}$. of diluent. No significant differences in flocculating properties were noted with the gamma globulin fraction from hepatitis sera when compared with a similar fraction from normal serum. In no instance, under similar conditions, did an albumin fraction give a positive flocculation.

It is noteworthy that the protein fractions used in these studies were separated electrophoretically in a phosphate buffer at $\mathrm{pH} 7.4$ near the isoelectric range ( $\mathrm{pH} 6$ to 7 ) of gamma globulin. The gamma globulin fraction obtained at a $\mathrm{pH}$ of 8.5 , using a barbital buffer, failed to show flocculating properties, even after dialyzing to restore the $\mathrm{pH}$ to 7.4 .
The effect of albumin from normal serum and from the serum of hepatitis on the flocculating properties of gamma globulin

A series of tubes was prepared containing diminishing amounts of isolated gamma globulin similar to those described above, and to each was added $5.9 \mathrm{mgm}$. (or $5.4 \mathrm{mgm}$.) of electrophoretically separated albumin (the approximate amount calculated to be present in $0.1 \mathrm{ml}$. of the normal serum used). Cephalin-cholesterol emulsion was then added in the usual fashion and the degree of flocculation recorded after 48 hours (Table II).

It will be noted that in the proportions used, considerable inhibition of the flocculating properties of the gamma globulin fraction is obtained with an albumin fraction from normal sources. In contrast, an equal amount of the albumin fraction from the 2 cases of hepatitis showed distinctly less inhibiting power on the flocculating properties of gamma globulin.

\section{DISCUSSION}

The elaboration of the serum albumins is usually ascribed to the liver. When this organ becomes diseased, such as in long-standing cirrhosis, a distinct drop in the serum albumin fraction is common, as well as an increase of serum globulin, especially of the gamma globulin fraction. It has recently been pointed out (4) that in acute hepatitis also, while similar changes are not striking by the usual salting-out methods (5), diminution of albumin and increase of gamma globulin are demonstrable by electrophoretic analysis. The studies

TABLE II

Comparison of inhibiting powers of albumin fraction of normal serum and of albumin fractions from cases of hepatitis

\begin{tabular}{|c|c|c|c|c|c|}
\hline & \multicolumn{5}{|c|}{ Gamma globulin fraction in diminishing amounts } \\
\hline & $0.55 \mathrm{mgm}$. & $0.44 \mathrm{mgm}$. & $0.33 \mathrm{mgm}$. & $0.22 \mathrm{mgm}$. & $0.11 \mathrm{mgm}$. \\
\hline \multirow[t]{2}{*}{$\begin{array}{l}\text { Gamma globulin fraction from hepatitis case I alone } \\
\text { Gamma globulin fraction from case I }+5.9 \mathrm{mgm} \text {. of albu- } \\
\text { min fraction from normal serum } \\
\text { Gamma globulin fraction from case I }+5.9 \mathrm{mgm} \text {. of albu- } \\
\text { min fraction from hepatitis case I }\end{array}$} & $\begin{array}{l}+++ \\
+++ \\
+++t\end{array}$ & $\begin{array}{l}+++ \\
++ \\
+++t\end{array}$ & $\begin{array}{c}++t \\
0 \\
++t\end{array}$ & $\begin{array}{l}+++ \\
0 \\
+++\end{array}$ & $\begin{array}{c}0 \\
0 \\
\text { QNS }\end{array}$ \\
\hline & 0.65 mgm. & $0.52 \mathrm{mgm}$. & $0.39 \mathrm{mgm}$. & $0.26 \mathrm{mgm}$. & $0.13 \mathrm{mgm}$. \\
\hline $\begin{array}{l}\text { Gamma globulin fraction from hepatitis case II alone } \\
\text { Gamma globulin fraction from case II plus } 5.4 \mathrm{mgm} \text {. of al- } \\
\text { bumin fraction from normal serum } \\
\text { Gamma globulin fraction from case II plus } 5.4 \mathrm{mgm} \text {. of al- } \\
\text { bumin fraction from hepatitis case II }\end{array}$ & $\begin{array}{c}+t+t \\
\pm \\
+t+\end{array}$ & $\begin{array}{c}+++ \\
\pm \\
+t+\end{array}$ & $\begin{array}{c}++t \\
0 \\
+\end{array}$ & $\begin{array}{c}++ \\
0 \\
0\end{array}$ & $\begin{array}{l}0 \\
0 \\
0\end{array}$ \\
\hline
\end{tabular}


TABLE III

Protein fractionation

\begin{tabular}{|c|c|c|c|c|c|c|c|c|c|c|c|}
\hline & \multicolumn{7}{|c|}{ Electrophoretic fractionation * } & \multicolumn{4}{|c|}{ Salt fractionation (Howe method (5)) } \\
\hline & \multirow{2}{*}{$\begin{array}{c}\text { Total } \\
\text { protein }\end{array}$} & \multirow{2}{*}{ Albumin } & \multicolumn{4}{|c|}{ Globulin } & \multirow{2}{*}{$\begin{array}{c}\text { A/G } \\
\text { ratio }\end{array}$} & \multirow{2}{*}{$\begin{array}{l}\text { Total } \\
\text { protein }\end{array}$} & \multirow{2}{*}{ Albumin } & \multirow{2}{*}{ Globulin } & \multirow{2}{*}{$\underset{\text { ratio }}{\text { A/G }}$} \\
\hline & & & $\alpha$ & $\boldsymbol{\beta}$ & $\boldsymbol{\gamma}$ & Total & & & & & \\
\hline Case II & 980 & $\begin{array}{c}485 \\
50 \\
\text { per } \\
\text { cent }\end{array}$ & $\begin{array}{c}100 \\
10 \\
\text { per } \\
\text { cent }\end{array}$ & $\begin{array}{c}185 \\
19 \\
\text { per } \\
\text { cent }\end{array}$ & $\begin{array}{c}210 \\
21 \\
\text { per } \\
\text { cent }\end{array}$ & $\begin{array}{c}495 \\
50 \\
\text { per } \\
\text { cent }\end{array}$ & 0.98 & 7.2 & 4.6 & 2.6 & 1.76 \\
\hline Normal & 1055 & $\begin{array}{c}665 \\
63 \\
\text { per } \\
\text { cent }\end{array}$ & $\begin{array}{c}80 \\
8 \\
\text { per } \\
\text { cent }\end{array}$ & $\begin{array}{c}195 \\
18 \\
\text { per } \\
\text { cent }\end{array}$ & $\begin{array}{c}115 \\
11 \\
\text { per } \\
\text { cent }\end{array}$ & $\begin{array}{c}390 \\
37 \\
\text { per } \\
\text { cent }\end{array}$ & 1.70 & 7.3 & 5.4 & 1.9 & 2.84 \\
\hline
\end{tabular}

* Expressed in arbitrary units and percentages derived from descending pattern areas. Buffer 0.02 $M$ sodium phosphate $+0.15 M \mathrm{NaCl}$; $\mathrm{pH} 7.4$.

reported here confirm these observations (Table III). The data presented indicate that during the active stage of hepatitis an alteration occurs in the albumin fraction as reflected by the cephalin flocculation reaction. The chemical nature of this alteration is at present under investigation. Profound changes in serum albumins have been demonstrated in nephrosis by immunological studies (6), and by electrophoresis (7), but modification of the albumin fraction in active hepatitis has not been recognized previously.

It is recognized that the effect on cephalin flocculation here described may not be a function of true albumin, and, until further investigation, should be considered a function of the fraction separated under the conditions employed. Subfractions of albumin have already been made and it is well recognized that the electrophoretic fraction used in these experiments represents a mixture.

A hypothesis for the mechanism of the cephalincholesterol flocculation reaction can therefore be advanced. The gamma globulin component of normal serum fails to bring about flocculation because of an inhibitory action exerted by substances in the electrophoretically separated albumin fraction. In disease, a positive flocculation may be obtained with a serum due to any of the following alterations: (1) Increase of gamma globulin in such quantity that there is insufficiency of the normal components of the serum albumin fraction to inhibit the reaction; (2) diminution of the serum albumin fraction below initial levels necessary to inhibit the reaction; (3) diminution in the flocculation-inhibiting properties of the albumin fraction, such as has been demonstrated above. The positive test observed in hepatitis, etc., is probably due to a combination of all these factors, especially to modification of the albumin fraction.

\section{CONCLUSIONS}

(1) The flocculation of a cephalin-cholesterol emulsion is observed with the isolated gamma globulin fraction obtained from normal serum, and from the serum of cases of hepatitis.

(2) The flocculating properties of gamma globulin are not affected in cases of hepatitis, although there may be an increase of this fraction in the serum during the course of the disease.

(3) The electrophoretically separated albumin fraction from normal sera in sufficient concentration tends to inhibit the flocculation of the gamma globulin fraction, whereas the albumin fractions from the sera of cases with hepatitis show relatively less inhibition of the flocculation.

(4) An hypothesis for the mechanism of the cephalin-cholesterol reaction is proposed.

\section{BIBLIOGRAPHY}

1. Hanger, F. M., Serological differentiation of obstructive from hepatogenous jaundice by flocculation of cephalin-cholesterol emulsions. J. Clin. Invest., 1939, 18, 261.

2. Kabat, E. A., Hanger, F. M., Moore, D. H., and Landow, $H$., The relation of cephalin flocculation 
and colloidal gold reactions to the serum proteins. J. Clin. Invest., 1943, 22, 563.

3. Hanger, F. M., The flocculation of cephalin-cholesterol emulsions by pathological sera. Tr. A. Am. Physicians, 1938, 53, 148.

4. Gray, S. J., and Barron, E. S. G., The electrophoretic analyses of serum proteins in diseases of the liver. J. Clin. Invest., 1943, 22, 191.
6. Howe, P. E., The determination of proteins in blooda micro method. J. Biol. Chem., 1921, 49, 109.

6. Goettsch, E., and Lyttle, J. D., Precipitin studies in nephrosis and nephritis. J. Clin. Invest., 1940, 19, 9.

7. Luetscher, J. A., Jr., Electrophoretic analysis of plasma and urinary proteins. J. Clin. Invest., 1940, 19, 313. 